\title{
Avaliação dos níveis de aglutininas anti-brucella em soros de caprinos de cinco centros de criação do nordeste do Brasil
}

\section{Evaluation of the anti-brucella antibodies levels of caprine serum from five farms in Brazilian northeast}

\author{
Clebert José Alves ${ }^{1}$, Silvio Arruda Valconcellos ${ }^{2}$, Zenaide M. Morais ${ }^{3}$, Ernande Arantes Leite', \\ Alberio Antonio Barros Gomes ${ }^{1}$
}

\section{Resumo}

Dentre os animais domésticos utilizados com finalidade econômica e social, o caprino tem valor destacado no meio rural da regiáo Nordeste do Brasil. A incidência da brucelose em caprinos e ovinos deslanados explorados no semi-árido nordestino, é pouco conhecida. O objetivo do presente trabalho foi investigar a ocorrência, ou não, de aglutininas antibrucella em cabras produtivas criadas em cinco centros de criação localizados no semi-árido paraibano. Para tanto, foram colhidas 915 amostras de soro sanguíneo de caprinos criados em diferentes microrregiōes. As amostras foram submetidas a avaliação pela prova de soro aglutinação rápida, apresentando resultado negativo.

Palavras chave: brucelose; caprinos; aglutininas; soro; Brucella melitensis

\section{Introdução}

Dentre as doenças ou infecções naturalmente transmissíveis entre os animais e 0 homem, a brucelose animal assume importância significativa na medida em que afeta a saúde animal, a economia da produçẩo pecuária, a saúde pública e a disponibilidade de proteína animal para as necessidades da população (Acha e Szyfres, 1986).

Nos caprinos, a espécie Brucella melitensis, considerada a mais patogênica para o homem, năo toi isolada no Brasil, diferentemente do que ocorreu em outras regiões, como a zona mediterrânea da Europa; Árica, Rússia e Américas Central e do Sul (Argentina e Peru).

Na brucelose caprina, devida a $B$, melifensis, a incidencia de aborto pode alcançar cerca de 40 a $60 \%$, ocorrendo no último terço da gestação. A contaminação ocorre através da ingestão de alimentos e água contaminada com microrganismos provenientes de fetos abortados e suas membranas ou das des- cargas genitais, como relatam Morrow (1986), e Alton (1973).

A brucelose em caprinos, provocada pela $B$. melitensis, parece ser muito semelhante à infecção correspondente nos bovinos. O aborto é a principal manifestação, persistindo a eliminação do agente através da excreção vaginal por cerca de três meses (Silva et al., 1983).

Os inquéritos sorológicos, realizados em diferentes partes do Brasil, apresentaram resultados variáveis. Rogick (1941), no Estado de São Paulo, examinando 1.000 cabras leiteiras, Silva et al. (1982), no Estado do Ceará, trabalhando com 1.334 caprinos e Brito (1985), estudando 347 amostras de soros caprinos provinientes do sul de Goiás e Distrito Federal, não encontraram qualquer reação positiva. Entretanto, outros pesquisadores registraram soro-aglutinaçao positiva oscilando entre 0,57 a 6,5\% [Carneiro (1933), Artigas (1934) e Neiva (1934) em São Paulo; Mosci (1944), França et al. (1954), Brito et al: (1971) no Rio de Janeiro; Costa et al. (1975) em Salvador apud Cunha et al (1979); Viegas et al. (1980), Silva et al. (1984)].

Face à importância da caprinocultura para a econômia da região Nordeste do Brasil e considerando os fatores responsáveis pela baixa produtividade observada no rebanho caprino, a qual atribui-se uma participação de $10 \%$ no abortamento, foi estruturado o presente trabalho, que teve como objetivo, pesquisar a ocorrência de aglutininas anti-brucella em cabras produtivas criadas em diferentes centros de criação do semi-árido paraibano.

\section{Material e Métodos}

Foram realizadas três colheitas de soro sanguíneo caprino, num total de 915 amostras, em diferentes épocas do ano, considerando-se, para cada centro de criação, os aspectos relacionados à localização em termos de microrregião.

\footnotetext{
Departamento de Medicina Veterinária, CSTR, Universidade Federal da Paraíba, Campus 7, Patos, PB, Brasil

${ }^{2}$ FMZV, Universidade de São Paulo, USP, Săo Paulo, SP, Brasilf

${ }^{3}$ Laboratório de Zoonoses Bacterianas, FMZV, USP, São Pauto, SP Brasil
} 
A localização e a quantidade de amostras colhidas foram as seguintes: microrregião do Curimataú Ocidental (Fazenda Pendência, Emepa) 229; microrregião do Cariri Ocidental (Fazenda Carnaúba) 260; microrregião de Patos (Nupeárido e São José) 264; microrregião do Brejo Paraibano (Bananeiras) 162 amostras.

As colheitas de sangue foram executadas por punção da veia jugular com seringas descartáveis; o sangue, transferido para frascos estéreis, foi imediatamente enviado ao laboratório.

As amostras foram submetidas à pesquisa de aglutininas anti-brucella, no Laboratório de Zoonoses Bacterianas da Faculdade de Medicina Veterinária, Universidade de São Paulo, pela prova rápida em placa, utilizando-se antígeno padrão fornecido pelo Ministério da Agricultura do Brasil.

\section{Resultados}

Os resultados das análises não evidenciaram a ocorrência de soro sanguíneo reagente positivo.

\section{Discussão}

A análise dos resultados obtidos, demonstrando a ausência de caprinos reagentes à brucelose, vem confirmar as informações anteriormente publicadas por Rogick (1941) e Silva e Silva (1983). Vale destacar, que estes autores trabalharam com uma quantidade significativa de amostras de soro sanguíneo de caprinos, respectivamente, 1.000 e 1.334 , não encontrando nenhum animal positivo.

Embora a ocorrência de abortos em caprinos seja alta, algo em torno de 10\% (Silva e Silva 1983), parece não ser a brucelose a sua causa principal, se considerarmos os dados obtidos no presente trabalho comparados com os achados de Rogick (1941) e Silva e Silva (1983).

A despeito da brucelose bovina apresentar uma prevalência baixa na região Nordeste e considerando a possibilidade da convivência direta entre as espécies bovina e caprina, somos levados a aceitar os argumentos de Caldas e Nesti (1958), quando salientam que a brucelose caprina causada pela espécie $B$. abortus, parece não ser um problema de magnitude maior, visto que a infecção nas cabras tem tendência a persistir por pouco tempo.

A falta de padronização nos procedimentos utilizados para a realização das provas sorológicas, bem como a dificuldade de se trabalhar com antígenos específicos, reforça a necessidade de que sejam observados critérios para a execução das referidas provas. Nesse sentido, as observações de Cunha et al. (1979), são pertinentes, na medida em que sugerem a utilização da prova de soro aglutinação rápida, apenas como um teste de triagem, recomendando ainda que os soros suspeitos e positivos sejam submetidos a confirmação pela prova lenta usando-se o mercapto-etanol.

A ausência de animais positivos revela que não houve associação positiva entre os determinantes do ambiente (influência de microrregião) e a doença.

Face às características peculiares relacionadas ao comportamento da brucelose em caprinos no Brasil, considerando a importância da caprinocultura no cenário nacional e diante das informações retrospectivas sobre a prevalência desta zoonose, se faz necessário reforçar as estratégias de controle sanitário dirigidas principalmente aos animais de raças especializadas originárias do continente europeu, objeto de importação, e que estão sendo introduzidas no Brasil.

\section{Abstract}

\section{Evaluation of the anti-brucella antibodies levels of} caprine serum from five farms in Brazilian northeast

In Brazilian northeast the caprine production has a high economic and social importance. The incidence of brucellosis in caprine and unwolled ovine is little known. The aim of the research was to determine the incidence of antibodies from caprine serum in the semi arid region of the State of Paraíba, Brazil. Nine-hundred fifteen blood samples were examined from five farms of different places in the semi-arid region. The samples were examined with the serum agglutination test. The results were negative.

\section{Key words: goats; antibodies; Brucella melitensis}

\section{Referências bibliográficas}

Acha PN, Szyfres B 1986. Zoonosis y enfermedades transmissibles comunes al hombre y a los animales. $2^{\text {a }}$ ed. Organización Panamericana de la Salud, Washington, $503 \mathrm{pp}$.

Alton GG 1973. Brucellosis in goats and sheep. World Anim Rev $5: 16-20$.

Brito DB, Reis CAB, Figueiredo JB 1971. Brucelose caprina no Estado da Guanabara. Rev Med Est Guanab Rio de Janeiro 38: 208-211.

Brito WMED 1985. Aspectos zoo-sanitários em caprinos de diferentes formas de exploração no sul de Goiás e Distrito Federal. Tese de mestrado, Escola de Veterinária da Universidade Federal de Minas Gerais, Belo Horizonte, $42 \mathrm{pp}$.

Caldas AD, Nesti A 1958. Ocorrência da brucelose caprina no Estado de São Paulo causada pela Brucella abortus. Arq Inst Biol 25: 139-149.

Cunha RG, Carvalho PM, Ferreira T 1979. Aglutininas para Brucella abortus em caprinos vacinados com Pasteurella multocida e Vibrio cholerae. Arq Esc Vet 31(1): 25-32.

Morrow DA 1986. Current therapy in theriogenology, diagnosis, treatment and prevention of reproductive diseases in small and large animals. WB Sanders 
Company, Philadelphia, 1143 pp.

Rogick FA 1941. Pesquisas sôbre a Brucelose caprina em São Paulo. Rev Ind Anim 4(1): 33-37.

Silva MUD, Silva EDF 1983. Possíveis causas de aborto em caprinos. Comunicado técnico. Embrapa-Centro Nacional de Pesquisa de caprinos 12, 1-9.

Silva AED, Silva MUD, Hansen D 1982. Brucelose (Brucella abortus) como possível causa de aborto, epididimoorquite em caprinos e ovinos no Ceará. Rev Bras Reprod Anim 6(1-2): 25-29.

Viegas EA, Viegas SARA, Caldas EM, Faria AF 1980. Investigaçăo sorológica para brucelose em caprinos e ovinos no Estado da Bahia. Arq EMV - UFBA 5(1): 99110. 